\title{
KLF2 Gene
}

National Cancer Institute

\section{Source}

National Cancer Institute. KLF2 Gene. NCI Thesaurus. Code C162389.

This gene is involved in the promotion of target gene expression. 